\title{
Common manifestation of airway diseases: chronic obstructive pulmonary disease and asthma bronchiale
}

\begin{abstract}
The differentiation of chronic obstructive pulmonary disease (COPD) and asthma bronchiale is often difficult. The airway inflammation is basicly different in two disease, but because of wide variety of phenotypes there is significant overlap (5$40 \%$ ) manifestation, in these cases we can speak about common manifestation. Pharmacotherapy has major effect on quality of life. There is not a mistake if we consider the common manifestation as asthma bronchiale bronchiale, and the basic therapy is inhaled corticosteroids and use anticholinergic or beta-mimetic bronchodilators as add on therapy. Proper therapy choice can help improve the quality of life and reduce the frequent and severe exacerbations.
\end{abstract}

Volume 2 Issue I - 2018

\author{
Janos Varga,' Maria Szilasi \\ 'National Koranyi Institute for TB and Pulmonology University, \\ Hungary \\ ${ }^{2}$ Department of Pulmonology, University of Debrecen, Hungary
}

Correspondence: János Varga, National Koranyi Institute for TB and Pulmonology University, Hungary, Tel +36 I39| 3374, Email varga@koranyi.hu

Received: October 23, 2017| Published: January 22, 2018

\section{Introduction}

Clinical symptoms can hardly differentiate COPD and asthma bronchial. $^{1-8}$ Significant smoking anamnesis can support COPD origin, but some asthma bronchialetic patients are smoker, also. ${ }^{9}$ Most of the asthma bronchialetic patients have paroxismatic dyspnoic wheezing in the early morning or after exercise. ${ }^{1-9}$ In COPD, the dyspnoea is progressive and it is manifested during exercise at first. Hey fever with obstructive pulmonary disease support the definition of allergic asthma bronchiale bronchiale, but there is a significant portion of COPD patients with hey fever as co-morbidity. ${ }^{10}$ Asthma bronchiale and COPD together show similar clinical feature as asthma bronchiale. ${ }^{1-8}$ Lung function is crucial for differentiation. In asthma bronchiale, most of the cases have reversible airway obstruction, lung function goes to normal values. ${ }^{10}$ The airway obstruction in COPD is irrevervisible or parthly reversible. ${ }^{9}$

\section{Definitions}

According to GINA 2017 definition, asthma bronchiale is a chronic inflammatory airway disease, in etiology take part different inflammatory cells and particulums. ${ }^{11}$ Inflammation related to bronchial hyperreactivity (BHR) results recurrent wheezing, episods of dyspnoea, chest thightness and coughing. ${ }^{11}$ Symptoms come mostly at night or in the early morning, it is worsening during exercise, and related to different degree of airway obstruction, which can be reversible with or without pharmacotherapy. According to GOLD 2017 guideline COPD is a preventable and treatable disease with extrapulmonary manifestations, which individuable worsen the condition. ${ }^{12}$ The characteristic of the disease is airflow limitation, which is not fully reversible. ${ }^{12}$ In general, the functional condition is progressive, and it is related to chronic inflammatory process of the lung. Etiological factors are inhalation of injurable material such as particulums and gases. Exacerbations and co-morbidites individually worsen the degree of the disease. ${ }^{12}$

Based on airway conditions there is two contraditary hypothesis of the common manifestation of the two disease. According to dutch hypothesis asthma bronchiale, chronic bronchitis and emphysema are a common genetical disease with different manifestations, in pathogenesis airway hyperreactivity is the main factor. ${ }^{3-8}$ According to british hypothesis chronic bronchitis, emphysema and asthma bronchialeare three different disease with three different clinical manifestations, three different origin and three different prognosis. Reversibility can help to differentiation. ${ }^{3-9}$ In the opposite part, international guidelines are dealing with asthma bronchiale and COPD common manifestation. According to GINA 2017, inhalatory exposition of injurable materials (mainly smoking) can cause a mixed inflammatory typical process of asthma bronchiale and COPD in patients with asthma bronchiale. In general, asthma bronchiale and COPD can differentiate, but in some patients with asthma bronchiale can manifest irreversible airway obstruction, and in theses cases the differentiation of the two diseases might be difficult $(4,11)$. According to GOLD 2017, the differentiation of chronic asthma bronchiale and COPD is not possible based on currently available radiological imaging and lung function tests. In these cases COPD and asthma bronchiale might be each other co-morbidities. ${ }^{4-12}$ The definition of COPD and asthma bronchiale in terms of common clinical manifestation is characteristics by variable airway obstruction, which is not fully reversible. ${ }^{13}$

\section{Obstructive lung diseases}

Obstructive lung diseases are the following: emphysema, COPD, reversible chronic bronchitis, asthma bronchiale, variable airway obstruction, COPD with asthma bronchialetic clinical feature, irreversible, atopic emphysema. ${ }^{14,15}$ Asthma bronchiale can devide different clinical entities, recent data support that a $\mathrm{T}_{\mathrm{H} 2}$ cell type and an non- $\mathrm{T}_{\mathrm{H} 2}$ pathophysiological pathway are present, also. ${ }^{16}$

\section{Epidemiological data}

Based on US data, $15,8 \%$ of obstructive lung diseases has COPD + asthma bronchialetogether in California (17). $15-30 \%$ of the obstructive patients has overlap in Europe. $24 \%$ of the severe asthma bronchialetic parients have COPD+asthma bronchiale from the 
same Californian database. ${ }^{18}$ According to a clinical study, common manifestation of COPD+asthma bronchialehas $42,7 \%$ frequevent exacerbation rate, and within this group $32,8 \%$ of these patients has severe exacerbation. ${ }^{19}$

\section{Airway reversibility}

The definition of reversible airway obstruction is more than $12 \%$ or at least $200 \mathrm{ml}$ increment from basic $\mathrm{FEV}_{1}$ after short-acting bronchodilator usage., ${ }^{4,11,12}$ Significant reversibility and normalisation of lung function support asthma bronchialediagnosis. ${ }^{11} \mathrm{COPD}+$ asthma bronchialecommon manifestation show acut or significant reversibility in lung function and eosinophilia in sputum. ${ }^{20}$

\section{airway resistemce}

Interleukin-6 as an inflammatory marker has role in the control of pathophysiological process in terms of airway resistence increment. ${ }^{13}$ The increment of airway resistence show the histological change (asthma bronchiale remodelling), but airway resistence is basicly high in COPD lead to flow limitation. ${ }^{9}$ Airway resistence is significantly different compared to the two diseases. ${ }^{14}$ In asthma bronchiale compared to COPD, airway resistence is lower in stable condition and in exacerbation, also. ${ }^{14}$

\section{Chest hyperinflation}

The chance of developing chronic resting and dynamic hyperinflation is high because of anatomical abnormalities, like alveolar wall disruption, airtrapping or expiratory flow limitation in COPD. Acut hyperinflation can develop in asthma bronchiale also, but the degree is much less and it can significantly reduce after the asthma bronchialetic attack. ${ }^{11}$

\section{Eosinophilic sputum}

There are data about counting of eosinophilic cells in the sputum in international literature, but it is not part of the daily routin in Hungary. Diagnosing of both diseases we need to focus clinical feature and lung function data. ${ }^{4-9}$

\section{Inflammatory cells in the airways}

There is inflammation in small- and big airway in asthma bronchiale. The count of T-cells, major basic proteins and mastocytes in small $(<2 \mathrm{~mm})$ and big $(>2 \mathrm{~mm})$ airway is not significantly different, however there is more activated eosinophils in small airways. ${ }^{14-18}$ Dominant neutrophilic inflammation takes part in COPD and the main characteristics are obstruction or closing of terminal bronchiolus. ${ }^{21}$ Favourable terapeutic effect can develop based on the influence of distal airways. ${ }^{21-25}$ Sufficient lung deposition leads to proper therapeutic effect in small airways. ${ }^{21}$

\section{Separated clinical entity}

In spanish COPD guideline, the COPD and asthma bronchiale common airway manifestation is a separated entity with the following criteria $^{3-27}$ (Figure 1):

\section{A. Major criteria}
i. Asthma bronchiale in anamnesis
ii. Significant reversibility: $\mathrm{FEV}_{1} \geq 15 \%$ and $\geq 400 \mathrm{ml}$
iii. Eosinophilic spurum

\section{B. Minor criteria}

i. Positive bronchodilator test (at least $2 \mathrm{x}: \mathrm{FEV}_{1} \geq 12 \%$ and $\geq 200 \mathrm{ml}$

ii. Atopy in anamnesis

iii. Increased $\operatorname{IgE}$

\section{Overlap is present, if COPD is present +}

D. 2 major criteria or

E. 1 major and 2 minor criteria

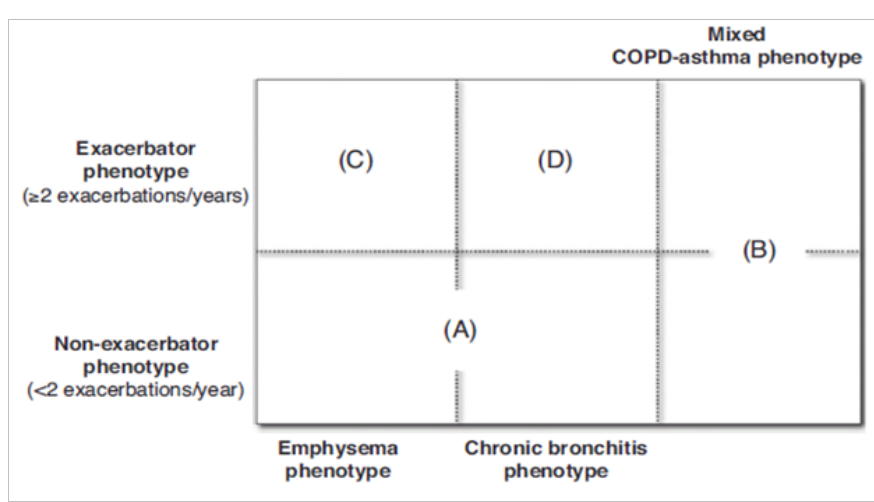

Figure I Spanish guideline, COPD+asthma bronchiale common fenotype. ${ }^{28}$

COPD, chronic obstructive pulmonary disease.

Recently published study compared to asthma bronchiale, COPD and asthma bronchiale+COPD common airway manifestation in terms of demographic data (Table 1), lung function, pathophysiologic variables (Table 2), characteristic inflammatory cell types (Table 3 ) and therapeutic option (Table 4) (Table 5). ${ }^{28,29}$ As a therapeutic guide if we can not decide whether the patient has asthma bronchiale or COPD we can treat the patient as asthma bronchialetic because leaving inhalative steroid in asthma bronchiale is dangerous. In COPD, we need to treat small airways, deliver pharmacotherapy to small airways. ${ }^{30-32}$ Betareceptor density is higher in small airways, and anticholinerg receptor density is higher in big airways. ${ }^{30-33}$ ICS+LABA combination can use the common, sinergistic effect of glucocorticoid and beta-adrenergic receptor. ${ }^{30,31}$ Cover all part of the surface of the airway is important, we need to achieve all therapeutic target. ${ }^{32}$ The following criteria can be used for COPD+asthma bronchiale common manifestation if a patient with COPD comes to the medical office:

a. Airway obstruction is variable, but not fully reversible in COPD

b. Positive bronchodilator test

c. Bronchial hyperreactivity

d. Asthma bronchiale in anamnesis

e. Atopy in anamnesis

f. Frequevent exacerbations

g. Smoking anamnesis 
Table I Demographic data and co-morbidities in the common manifestation of COPD and asthma (Modified based on. ${ }^{19}$

\begin{tabular}{|c|c|c|c|}
\hline Disease & Asthma (Severe) & Asthma+ Copd & Copd \\
\hline \multirow{11}{*}{$\begin{array}{l}\text { Demographic } \\
\text { Data }\end{array}$} & $>40$ years & $>40$ years, $50-65$ years & $>65$ years \\
\hline & Female $>$ Male & smoker or ex-smoker & smoker or ex-smoker \\
\hline & $\begin{array}{l}\text { ex-smoker or }<5 \text { py smoking } \\
\text { history }\end{array}$ & > 10 py smoking history & >I0 py smoking history \\
\hline & obesity & atopy & atopy is absent \\
\hline & typic atopy & Rhinosinusitis & GERD \\
\hline & rhinosinusitis & GERD & daily albuterol usage \\
\hline & GERD & significantly reduced exercise tolerance & significantly reduced exercise tolerance \\
\hline & Frequent albuterol usage & $\begin{array}{l}\text { main problem: very frequent exacerbations> } \\
\text { COPD alone }\end{array}$ & oxygen-dependent \\
\hline & \multicolumn{2}{|c|}{ Limited exercise tolerance between worse conditions } & $\begin{array}{l}\text { main problem: exacerbations, reduced exercise } \\
\text { tolerance }\end{array}$ \\
\hline & \multicolumn{3}{|l|}{ prednisolon-dependency } \\
\hline & \multicolumn{3}{|c|}{ main problem: frequent exacerbations } \\
\hline
\end{tabular}

COPD, chronic obstructive pulmonary disease; GERD, gastroesophageal reflux disease.

Table 2 Functional variables, clinical features in COPD, asthma and common manifestation of the two disease modification based on. ${ }^{30}$

\begin{tabular}{|c|c|c|c|}
\hline Disease & Asthma & Asthma+Copd & Copd \\
\hline & $\begin{array}{l}\text { From moderate to severe intermittent } \\
\text { or chronic airway obstruction }\end{array}$ & $\begin{array}{l}\text { From moderate to severe intermittent } \\
\text { or chronic airway obstruction }\end{array}$ & $\begin{array}{l}\text { From modrate to severe chronic airway obstruction } \\
\text { (GOLD II-IV) }\end{array}$ \\
\hline & $\mathrm{FEV}_{1} / \mathrm{FVC}<0.70$ & $\mathrm{FEV}_{1} / \mathrm{FVC}<0.70$ & DLCO $<80 \%$ pred \\
\hline & $\begin{array}{l}\mathrm{FEV},<68 \% \text { pred, }>\text { or }<65 \% \text { pred after } \\
\text { albuterol usage }\end{array}$ & $\begin{array}{l}\mathrm{FEV}_{1}<68 \% \text { pred, or }<65 \% \text { pred after } \\
\text { albuterol usage }\end{array}$ & $\mathrm{FeNO}>25 \mathrm{ppb}$ \\
\hline & SARP cluster 3,4 or 5 & DLCO normal or low & Static or dynamic hyperinflation \\
\hline & DLCO normal & $\mathrm{FeNO}>25-50 \mathrm{ppb}$ & exacerbation $>2 /$ year if $\mathrm{FEV}_{1}<50 \%$ pred \\
\hline & $>3 \%$ eosinophilic sputum & Static hyperinflation & Not frequent awakeness at night \\
\hline & \multirow[t]{2}{*}{$>3$ exacerbation/year } & $>3-5$ exacerbation/year & \\
\hline & & frequent awakness, $>4 /$ weak & \\
\hline
\end{tabular}

COPD, chronic obstructive pulmonary disease, $\mathrm{FEV}_{1}$, forced expiratory volume in the first second, $\mathrm{FVC}$, forced vital capacity; $\mathrm{DL}_{\mathrm{co}}$, diffusion capacity; FeNO, exhaled fractioned nitrogen-monoxide

Table 3 Pathophysiologic background of COPD, asthma and common manifestation of the two disease (Modification based on. ${ }^{32}$

\begin{tabular}{|c|c|c|c|}
\hline Disease & Asthma & Asthma+Copd & Copd \\
\hline \multirow{7}{*}{$\begin{array}{l}\text { Pathophysiologic } \\
\text { background }\end{array}$} & $\begin{array}{l}\text { airway inflammation: } \\
\text { eosinophil>neutrophil }\end{array}$ & $\begin{array}{l}\text { airway inflammation: eosinophil + neutrophil, CD4+, CD8+ } \\
\text { T-limfocytes }\end{array}$ & emphysema, alveolar destruction \\
\hline & mastocytes & $\begin{array}{l}\text { alveolar macrophages, smooth muscle } \\
\text { hyperplasia } \pm \text { emphysema }\end{array}$ & $\begin{array}{l}\text { airway inflammation: } \\
\text { neutrophil>eosinophil }\end{array}$ \\
\hline & & & CD4+, CD8+ T-lymphocytes \\
\hline & CD4+ T-lymphocytes & peribronchiolar fibrosis & alveolar macrophages \\
\hline & $\begin{array}{l}\text { smooth muscle hyperplasy and } \\
\text { hypertrophy }\end{array}$ & IgE, IL-4, IL-5, IL-I 3, IL-8, IL-6, TNF-alfa, eotaxin, proteases & mastocytes? \\
\hline & no emphysema & & peribronchiolar fibrosis \\
\hline & IgE, IL-4, IL-5, IL-I 3, eotaxin & & IL-6, IL-8,TNF-alfa, proteases \\
\hline
\end{tabular}

COPD, chronic obstructive pulmonary disease; IgE, immunglobulin-e; IL, interleukine;TNF, tumor necrosis faktor. 
Table 4 Pharmacotherapy of COPD, asthma and common manifestation of the two disease

\begin{tabular}{|c|c|c|c|}
\hline Disease & Asthma & Asthma+COPD & COPD \\
\hline $\begin{array}{l}\text { First-choice } \\
\text { pharmacoterapy }\end{array}$ & ICS, ICS+LABA & $\begin{array}{l}I C S \pm L A M A \pm L A B A, \text { smoking cessation, } \\
\text { pulmonary rehabilitation }\end{array}$ & $\begin{array}{l}\text { bronchodilator-LAMA or LABA or both smoking } \\
\text { cessation pulmonary rehabilitation }\end{array}$ \\
\hline Add on therapy & $\begin{array}{l}\text { LABA, LAMA, LTRA, teofillin, } \\
\text { omalizumab, prednisolon }\end{array}$ & $\begin{array}{l}\text { LABA, LAMA, LTRA, or roflumilast or } \\
\text { teofillin, omalizumab, prednisolon }\end{array}$ & ICS Or Roflumilast, Teofillin \\
\hline Optional therapy & $\begin{array}{l}\text { Anti IL-5, Anti IL-I } 3 \text { ICS+LABA } \\
\text { Ix/Day Azitromycin Vaccines } \\
\text { broncial thermoplasty }\end{array}$ & $\begin{array}{l}\text { therapy of asthma and COPD according } \\
\text { to FeNO values and endotypes }\end{array}$ & $\begin{array}{l}\text { LAMA+LABA Ix/Day, Carbocystein, Azitromycin } \\
\text { anti IL-8, p39 protein kinase inhibitors hemophylus } \\
\text { influenza vaccine endobronchial valves lung } \\
\text { transplantation }\end{array}$ \\
\hline
\end{tabular}

ICS, Inhalative Corticosteroid; LABA, Long-Acting Beta-Agonist Bronchodilator; LAMA, Long-Acting Anticholinergic Bronchodilator; LTRA, Leukotrien Antagonist; IL, Interleukine; FeNO, Exhaled Fractioned Nitrogen-Monoxide

Table 5 Spanish guideline, pharmacotherapy of COPD, asthma and common manifestation of the two disease (modified based on. ${ }^{28}$

\begin{tabular}{|c|c|c|c|c|}
\hline \multirow[t]{2}{*}{ Fenotypes } & \multicolumn{4}{|l|}{ Stages } \\
\hline & I & II & III & IV \\
\hline A & LAMA or LABA & LAMA or LABA & $L A M A+L A B A$ & LAMA+LABA+teofillim \\
\hline $\begin{array}{l}\text { Non-exacerbator with emphysema } \\
\text { or chronic bronchitis }\end{array}$ & SABA or SAMA & $L A M A+L A B A$ & & \\
\hline $\begin{array}{l}\text { B } \\
\text { Mixed COPD-asthma }\end{array}$ & $\mathrm{LABA}+\mathrm{ICS}$ & $\mathrm{LABA}+\mathrm{ICS}$ & $L A M A+L A B A+I C S$ & $\begin{array}{l}L A M A+L A B A+I C S \\
\text { (if needed teofillin or PDE4 inhibitor) }\end{array}$ \\
\hline C & & $($ LABA or LAMA $)+I C S$ & $L A M A+L A B A+I C S$ & $L A M A+L A B A+I C S$ \\
\hline Exacerbator type with emphysema & LAMA or LABA & $\begin{array}{l}\text { LAMA }+ \text { LABA } \\
\text { LAMA or LABA }\end{array}$ & & (if needed teofilin) \\
\hline D & & $\begin{array}{l}\text { LAMA or LABA + (ICS } \\
\text { or PDE4 inhibitor) }\end{array}$ & $\begin{array}{l}\text { LAMA+LABA+ (ICS or } \\
\text { PDE4 inhibitor) }\end{array}$ & $\begin{array}{l}\mathrm{LAMA}+\mathrm{LABA}+(\mathrm{ICS} \text { or PDE4 } \\
\text { inhibitor) }\end{array}$ \\
\hline $\begin{array}{l}\text { Exacerbator type with chronic } \\
\text { bronchitis }\end{array}$ & LAMA or LABA & LAMA+LAMA & $\begin{array}{l}\text { LAMA or LABA+ } \\
\text { (teofillin+PD4 inhibitor) }\end{array}$ & $\begin{array}{l}\text { LAMA + LABA + ICS + PDE4 } \\
\text { inhibitor }\end{array}$ \\
\hline & & LAMA or LABA & If needed carbocystein) & $\begin{array}{l}\text { (if needed carbocystein } \pm \text { teofillin } \\
\pm \text { antibiotics) }\end{array}$ \\
\hline
\end{tabular}

COPD, chronic obstructive pulmonary disease; LAMA, long-acting anticholinergic bronhodilator; LABA, long-acting beta-agonist bronchodilator; SAMA, shortacting anticholinergic bronchodilator;SABA, short-acting beta-agonist bronchodilator; ICS, inhalative corticosteroid; PDE4 inhibitor, phosphodiesterase4 inhibitor.

\section{Case report}

43years female patient, who had symptoms of hey fever for 10 years and 3times/week awoke in the early morning before using bronchodilators for 5years. She was a passive smoker and she had 15 py (pack year=pack/day x smoking years) smoking history. In stable condition lung funtion was the following after reversibility test ( $\mathrm{FEV}_{1}: 1,53 \mathrm{~L}$ (52\%pred)-1,87L (80\%pred), FVC:2,53L (63\%pred)2,98L (92\%pred), $\mathrm{FEV}_{1} / \mathrm{FVC}: 65-68 \%$. The patient had frequevent clinical worsening with wheezing and she often need to have medical service. Outcomes: As an additional treatment ICS was chosen, and the exacerbations was disappeared, quality of life and lung function improved significantly, but lung function was fixed at a mild obstruction level. We offered a smoking cessation program for this patient, also. If the following patient with asthma bronchiale comes to medical office we need to think about asthma bronchiale bronchiale+COPD common manifestation, and to use anticholinergic bronchodilator as add-on therapy:

a. Smoking asthma bronchialetic patient

b. Uncontrolled patients with asthma bronchiale on fix combination (ICS+LABA) therapy c. Airway obstruction shows only small reversibility or fixed.

\section{Case report}

46years male patient with asthma bronchiale, who smoked 10cigerrates/day for 20years (10py smoking history). Using ICS+LABA combination he had not significant early morning paroxism, but he had a progressive exertional dyspnoea. He had reduced daily activity, also. Lung function parameters (reversibility test): $\mathrm{FEV}_{1}:$ 1,53L(43\%pred)-1,65L(47\%pred), FVC: 2,54L(72\%pred)-2,68(76\%pred), FEV,/FVC: 59-61\%. Outcomes: An anticholinergic add-on therapy seemed to achieve the reduction in lung function worsening. Complex pulmonary rehabilitation (basicly chest physiotherapy+training programs) was recommened for reduction of dyspnoea and increase of daily activity. Smoking cessation was suggested to the patient. Hospital and therapeutic cost. These type of patients come to medical office more often, so it causes significantly more health and financial cost. The cost of COPD+asthma bronchiale common manifestation is true:

a. The treatment cost of asthma bronchiale+COPD common manifestation's patient is significantly larger 
b. Severe exacerbation is often, wich is very expensive. ${ }^{34-36}$

\section{Conclusion}

According to an American study, the cost of yearly treatment if only asthma bronchiale is manifested is $2.307 \mathrm{USD}$, if COPD is $4.879 \mathrm{USD}$, but 14.924 USD if the two disease is common manifested. In summary, asthma bronchialeand COPD can be manifested not just separetaly, the ratio of common manifestation is $15-30 \%$ in the obstructive group. Inflammatory response, lung function, value of exhaled, fractioned nitrogen-monoxide can be typical in these patients. If the two disease are common manifested add on anticholinergic therapy lead to better quality of life if asthma bronchialetic paients has COPD and in patients with COPD add on ICS therapy lead to better quality of life and reduction in exacerbation rate if astma is manifested also. Acceptable quality of life, reduction in the rate of hospitalisations and exacerbations can be achieved with proper pharmacotherapy control. Smoking cessation and pulmonary rehabilitation are neccesary for the complex treatment of these patients, also.

\section{Acknowledgements}

None.

\section{Conflict of interest}

The authors declare that there is no conflict of interest.

\section{References}

1. Tochino Y, Asai K, Shuto T, et al. Asthma-COPD overlap syndromeCoexistence of chronic obstructive pulmonary disease and asthma in elderly patients and parameters for their differentiation. J Gen Fam Med. 2017;18(1): 5-11.

2. Kurashima K, Takaku Y, Ohta C, et al. Smoking history and emphysema in asthma-COPD overlap. Int $J$ Chron Obstruct Pulmon Dis. 2017;12(1):3523-3532.

3. Chambliss JM, Sur S, Tripple JW. Asthma versus chronic obstructive pulmonary disease, the Dutch versus British hypothesis, and role of interleukin-5. Curr Opin Allergy Clin Immunol. 2018;18(1):26-31.

4. Varga J, Szilasi M. A krónikus obstruktív tüdőbetegség és az asthma bronchiale együttes légúti manifesztációja. AMEGA. 2017;2:11-16.

5. Pérez de Llano L, Cosío BG, Miravitlles M, et al. Accuracy of a New Algorithm to Identify Asthma-COPD Overlap (ACO) Patients in a Cohort of Patients with Chronic Obstructive Airway Disease. Arch Bronconeumol. 2017;S0300-2896(17):30396-30404.

6. Pérez-de-Llano L, Cosio BG, CHACOS study group. Asthma-COPD overlap is not a homogeneous disorder: further supporting data. Respir Res. 2017;18(1):183

7. Agustí A, Bafadhel M, Beasley R, et al. Precision medicine in airway diseases: moving to clinical practice. Eur Respir J. 2017;50(4):1701655.

8. Müller V, Gálffy G, Tamási L. Asthma and chronic obstructive pulmonary disease overlap]. Orv Hetil. 2011;152(3):114-118.

9. Varga J. Krónikus obstruktív tüdőbetegség (COPD). Háziorvosi Továbbképző Szemle XV. 2010;(1):2-6.

10. Herjavecz I. Böszörményi Nagy Gy:Asthma bronchiale. Bp. Springer Hungarica, 2010;1355:45-59.

11. http://ginasthma.org/

12. http://goldcopd.org/

13. Gibson PG, Simpson JL. The overlap syndrome of asthma and COPD: what are its features and how important is it? Thorax. 2009;64(8):728735 .
14. Jalusic Gluncic T. What happens with airway resistance (RAW) in asthma and COPD exacerbation. Med Arh. 2011;65(5):270-273.

15. Snider GL. Chronic obstructive pulmonary disease: a definition and implications of structural determinants of airflow obstruction for epidemiology. Am Rev Respir Dis. 1989;140(3 Pt 2):3S-8S.

16. Wenzel SE. Asthma phenotypes: the evolution from clinical to molecular approaches. Nat Med. 2012;18(5):716-725.

17. Soriano JB, Davis KJ, Coleman B, et al. The proportional Venn diagram of obstructive lung disease: two approximations from the United States and the United Kingdom. Chest. 2003;124(2):474-481.

18. Rubini A. Interleukin-6 and Lung Inflammation: Evidences of A Causing Role in Inducing Respiratory System Resistance Increments. Inflamm Allergy Drug Targets. 2013. p. 10.

19. Zeki AA, Schivo M, Chan A, et al. The Asthma-COPD Overlap Syndrome: A Common Clinical Problem in the Elderly. J Allergy (Cairo). 2011. p. 861926.

20. Hardin M, Silverman EK, Barr RG, et al. The clinical features of the overlap between COPD and asthma. Respir Res. 2011;12:127.

21. Kitaguchi Y, Komatsu Y, Fujimoto K, et al. Sputum eosinophilia can predict responsiveness to inhaled corticosteroid treatment in patients with overlap syndrome of COPD and asthma. Int $J$ Chron Obstruct Pulmon Dis. 2012;7:283-289.

22. Usmani OS, Barnes PJ. Assessing and treating small airways disease in asthma and chronic obstructive pulmonary disease. Ann Med. 2012;44(2):146-156.

23. Tulic MK, Christodoulopoulos P, Hamid Q. Small airway inflammation in asthma. Respir Res. 2001;2(6):333-339.

24. van den Berge $\mathrm{M}$, ten Hacken $\mathrm{NH}$, Cohen $\mathrm{J}$, et al Small airway disease in asthma and COPD: clinical implications. Chest. 2011;139(2):412-423.

25. McDonough JE, Yuan R, Suzuki M, et al. Small-airway obstruction and emphysema in chronic obstructive pulmonary disease. $N$ Engl $J$ Med. 2011;365(17):1567-1575.

26. Tashkin DP. The role of small airway inflammation in asthma. Allergy Asthma Proc. 2002;23(4):233-242.

27. Soler Cataluña JJ, Cosío B, Izquierdo JL, et al. Consensus document on the overlap phenotype COPD-asthma in COPD. Arch Bronconeumol. 2012;48(9):331-337.

28. Miravitlles M, Soler Cataluña JJ, Calle M, Molina J, et al. Spanish Society of Pulmonology and Thoracic Surgery. Spanish COPD Guidelines (GesEPOC): pharmacological treatment of stable COPD. Spanish Society of Pulmonology and Thoracic Surgery. Arch Bronconeumol. 2012;48(7):247-257.

29. Miravitlles M, Soler Cataluña JJ, Calle M, et al. Treatment of COPD by clinical phenotypes: putting old evidence into clinical practice. Eur Respir J. 2013;41(6):1252-1256.

30. Louie S, Zeki AA, Schivo M, et al. The asthma-chronic obstructive pulmonary disease overlap syndrome: pharmacotherapeutic considerations. Expert Rev Clin Pharmacol. 2013;6(2):197-219.

31. Mitzner W. Emphysema-a disease of small airways or lung parenchyma? N Engl J Med. 2011;365(17):1637-1639.

32. Louie S, Zeki AA, Schivo M, et al. The asthma-chronic obstructive pulmonary disease overlap syndrome: pharmacotherapeutic considerations. Expert Rev Clin Pharmacol. 2013;6(2):197-219.

33. Hamid QA, Mak JC, Sheppard MN, et al. Localization of beta 2-adrenoceptor messenger RNA in human and rat lung using in situ hybridization: correlation with receptor autoradiography. Eur $J$ Pharmacol. 1991;206(2):133-138. 
34. Adcock IM, Gilbey T, Gelder CM, et al. Glucocorticoid receptor localization in normal and asthmatic lung. Am J Respir Crit Care Med. 1996;154(3 Pt 1):771-782.

35. Lipworth BJ. Targets for inhaled treatment. Respir Med. 2000;94(Supp D): $13 \mathrm{~S}-16 \mathrm{~S}$.
36. Shaya FT, Dongyi D, Akazawa MO, et al. Burden of concomitant asthma and COPD in a Medicaid population. Chest. 2008;134(1):14-19. 